\section{Omental infarction in an obese 10-year-old boy}

\author{
Katerina Kambouri,1 Stefanos Gardikis,1 \\ Alexandra Giatromanolaki, 2 \\ Aggelos Tsalkidis, ${ }^{3}$ Efthimios Sivridis, ${ }^{2}$ \\ George Vaos 1,4 \\ Departments of 1Pediatric Surgery, \\ 2Pathology and 3 Pediatrics, 4 Laboratory \\ of Experimental Surgery \& Surgical \\ Research, Alexandroupolis University \\ Hospital, Democritus University of \\ Thrace, School of Medicine, \\ Alexandroupolis, Greece
}

\section{Abstract}

Primary omental infarction (POI) has a low incidence worldwide, with most cases occurring in adults. This condition is rarely considered in the differential diagnosis of acute abdominal pain in childhood. Herein, we present a case of omental infarction in an obese 10 -year-old boy who presented with acute abdominal pain in the right lower abdomen. The ultrasound (US) examination did not reveal the appendix but showed secondary signs suggesting acute appendicitis. The child was thus operated on under the preoperative diagnosis of acute appendicitis but the intraoperative finding was omental infarct. Since the omental infarct as etiology of acute abdominal pain is uncommon, we highlight some of the possible etiologies and emphasize the importance of accurate diagnosis and appropriate treatment of omental infarction.

\section{Introduction}

Abdominal pain is a common complaint in children presenting to the emergency room. The differential diagnosis includes serious surgical pathologies such as acute appendicitis, intussusceptions, malrotation, and torsion of the gonads, all of which require prompt intervention. In children, primary omental infarction (POI) is rarely considered in the differential diagnosis of acute abdominal pain. This condition has a low incidence worldwide, with most cases occurring in adults; in the pediatric population, POI accounts for approximately $15 \%$ of all cases reported. ${ }^{1}$ We present herein a case of POI in an obese 10-year-old boy who presented with clinical, hematological, and radiological findings of acute appendicitis.

\section{Case Report}

A 10-year-old boy was admitted to our department due to acute abdominal pain of $8 \mathrm{~h}$ duration, with nausea and two episodes of vomiting. The child had no significant past medical history, but he was obese, weighing $61.5 \mathrm{~kg}$. The physical examination revealed marked abdominal tenderness localized to the right lower abdomen. His temperature was $37.2^{\circ} \mathrm{C}$, and a laboratory investigation revealed a white blood cell count of 9000 leukocytes $/ \mathrm{mm}^{3}$, with neutrophilia (85.6\%) and elevated C-reactive protein $(1.4 \mathrm{mg} / \mathrm{dL})$ and erythrocyte sedimentation rate (30 $\mathrm{mm} / \mathrm{h}$ ). All other hematological and biochemical parameters were within normal ranges. An ultrasound (US) examination did not reveal the appendix, but showed secondary findings compatible with appendicitis, such as free peritoneal fluid in Douglas' space and among the distended bowel loops in the right abdomen. The child was thus operated on under the preoperative diagnosis of acute appendicitis. The right iliac fossa was explored and a small amount of serous fluid was found. A grossly inflamed omental mass was seen in the right lower quadrant and a partial omental resection was undertaken (Figure 1). The cecum was found in a high position and the appendix was retrocecal, below the liver, and had a normal macroscopic appearance. An appendicectomy was performed. The pathology of the surgical specimens revealed primary omentitis and an appendix without inflammation (Figure 2). The patient's postoperative course was uneventful and he was discharged on the second postoperative day.

Written informed consent was obtained from the patient for publication of this case report and any accompanying images. A copy of the written consent is available for review by the Editor-in-Chief of this journal.

\section{Discussion}

POI is an uncommon condition that may present as acute abdomen in any age group, but mainly in the fourth and fifth decade of life, and with a male-to-female ratio of 2:1.2 Most authors support the hypothesis that it is associated with an anomalous and fragile blood supply of the right lower portion of the omentum, which is consequently susceptible to infarction. ${ }^{3}$ It can be provoked by kinking of veins caused by the patient's position or vascular congestion after large meals, and abrupt increases in intraabdominal pressure following coughing. Varjavandi et al. ${ }^{4}$ and Loh et al. ${ }^{5}$ recently suggested that obese children are also predisposed to omental infarction. They postu-
Correspondence: George Vaos, Department of Paediatric Surgery and Laboratory of Experimental Surgery \& Surgical Research, Alexandroupolis University Hospital, Democritus University of Thrace School of Medicine, 68100 Alexandroupolis, Greece.

Tel: +30.2551 .0 .76135 - Fax: +30.2551 .0 .30493 .

E-mail: gvaos@med.duth.gr

Key words: abdominal pain; children; omental infarction.

Conflict of interest: the authors report no conflicts of interest.

Contributions: KK, SG, AG, GV, study design; KK, AG, AT, GV, manuscript writing; KK, patient follow up; SG, ES data analysis and interpretation; SG, AT, patient assessment; SG, final manuscript drafting; AT, literature reviewing; ES, manuscript reviewing; GV, final manuscript approval.

Received for publication: 13 June 2011. Accepted for publication: 4 August 2011.

This work is licensed under a Creative Commons Attribution NonCommercial 3.0 License (CC BYNC 3.0).

(C) Copyright K. Kambouri et al., 2011

Licensee PAGEPress, Italy

Pediatric Reports 2011; 3:e22

doi:10.4081/pr.2011.e22

lated that increased fat deposition outstrips the blood supply to the developing omentum, causing relative ischemia from traction. Our case supports this hypothesis since our patient was an obese child.

A literature review revealed a few series involving children $1,2,4-9$ and some sporadic isolated cases. 10 Table 1 lists 8 series of pediatric POI including 88 patients (61 males and 27 females) that have been reported in the recent English-language literature. The average POI patient age ranges from 6.5 to 12.5 years. US was performed in 28 patients and computed tomography (CT) in 31. A preoperative diagnosis of POI could be made in 50 of these patients. Surgery was performed in 70 patients, while in 18 the treatment was conservative. However, the true incidence of this entity is underestimated. It is believed that in recent years there has been an increasing prevalence of POI in children, which appears to coincide with the increased prevalence of obesity in children. 4

In most cases POI can be diagnosed either by abdominal US or CT. ${ }^{5}$ Nevertheless, there are cases wherein the omental infarct was found in children undergoing abdominal exploration for acute appendicitis, ${ }^{1}$ such as our patient, in whom US could not reveal the appendix, which was positioned in a high retrocecal position, and the distended bowel 


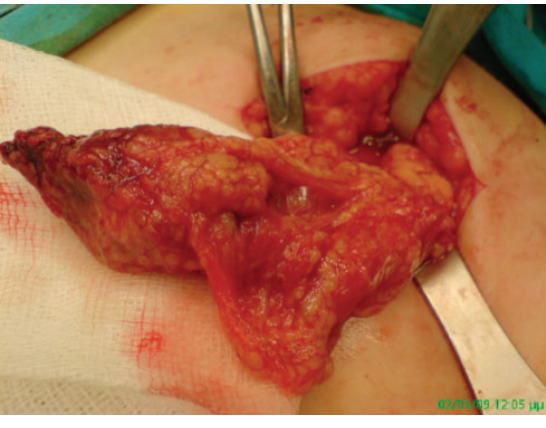

Figure 1. Omental inflammatory mass with signs of necrotic tissue.

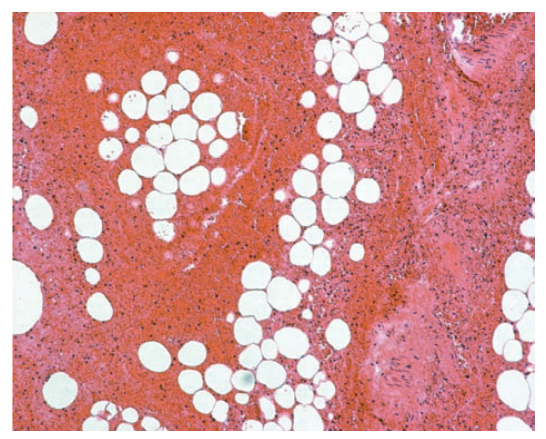

Figure 2. Histology of the strangulated omentum showing subtotal haemorrhagic necrosis/infarction (H\&E stain; original magnification X200).

Table 1. Reported series of primary omental infarction.

\begin{tabular}{|c|c|c|c|c|c|c|}
\hline $\begin{array}{l}\text { Authors } \\
\text { (year reported) }\end{array}$ & $\begin{array}{l}\text { Patients } \\
\text { No. }\end{array}$ & $\begin{array}{l}\text { Average } \\
\text { age }\end{array}$ & Sex & $\begin{array}{l}\text { Presentation } \\
\text { (No.) }\end{array}$ & $\begin{array}{l}\text { Pre-operative } \\
\text { diagnosis with } \\
\text { imaging studies } \\
\text { (No.) }\end{array}$ & Treatment \\
\hline $\begin{array}{l}\text { Schlesinger et al. } \\
\text { (1999) }\end{array}$ & 9 & $81 / 2$ years & $\frac{7 m}{2 f}$ & $\begin{array}{c}\text { Abdominal pain (9) } \\
\text { Fever (4) } \\
\text { Nausea (3) }\end{array}$ & $\begin{array}{c}\mathrm{US}(6) \\
\mathrm{US}+\mathrm{CT}(1)\end{array}$ & Surgical (9) \\
\hline $\begin{array}{l}\text { Helmrath et al. }{ }^{2} \\
\text { (2001) }\end{array}$ & 18 & $71 / 2$ years & $\begin{array}{c}12 \mathrm{~m} \\
6 \mathrm{f}\end{array}$ & $\begin{array}{l}\text { Abdominal pain(18) } \\
\text { Anorexia - nausea (5) } \\
\text { Fever (3) }\end{array}$ & $\begin{array}{l}\text { US (4) } \\
\text { CT (2) }\end{array}$ & Surgical (18) \\
\hline $\begin{array}{l}\text { Varjavandi et al. }{ }^{4} \\
\text { (2003) }\end{array}$ & 4 & $12 \frac{1}{2}$ years & $\begin{array}{l}3 \mathrm{~m} \\
\text { 1f }\end{array}$ & Abdominal pain (4) & CT (3) & Surgical (4) \\
\hline $\begin{array}{l}\text { Lee et al. }{ }^{9} \\
(2005)\end{array}$ & 6 & $61 / 2$ years & $\begin{array}{l}5 \mathrm{~m} \\
1 \mathrm{f}\end{array}$ & $\begin{array}{c}\text { Abdominal pain (6) } \\
\text { Fever (3) } \\
\text { Vomit (1) }\end{array}$ & CT (2) & Surgical (6) \\
\hline $\begin{array}{l}\text { Baldisserotto et al.7 } \\
\text { (2005) }\end{array}$ & 10 & $71 \frac{1}{2}$ years & $\begin{array}{l}8 m \\
2 f\end{array}$ & $\begin{array}{c}\text { Abdominal pain (10) } \\
\text { Fever (1) }\end{array}$ & US (6) & Surgical (10) \\
\hline $\begin{array}{l}\text { Loh et al. } 5 \\
(2005)\end{array}$ & 12 & $91 / 2$ years & $\begin{array}{c}10 m \\
2 f\end{array}$ & $\begin{array}{l}\text { Abdominal pain (12) } \\
\text { Fever (9) }\end{array}$ & CT (4) & Surgical (12) \\
\hline $\begin{array}{l}\text { Nubi et al. } 1 \\
(2009)\end{array}$ & 10 & 9,1 years & $\begin{array}{c}6 \mathrm{~m} \\
4 \mathrm{f}\end{array}$ & $\begin{array}{c}\text { Abdominal pain (10) } \\
\text { Fever (5) } \\
\text { Nausea (3) }\end{array}$ & $\begin{array}{l}\text { US (2) } \\
\text { CT (10) }\end{array}$ & $\begin{array}{c}\text { Surgical (6) } \\
\text { Conservative (4) }\end{array}$ \\
\hline $\begin{array}{l}\text { Rimon et al. }{ }^{\circ} \\
(2009)\end{array}$ & 19 & 9,3 years & $\begin{array}{c}10 m \\
9 f\end{array}$ & $\begin{array}{l}\text { Abdominal pain (19) } \\
\text { Nausea vomiting (12) } \\
\text { Fever (4) }\end{array}$ & $\begin{array}{l}\operatorname{US}(9) \\
\text { CT (9) }\end{array}$ & $\begin{array}{c}\text { Surgical (5) } \\
\text { Conservative (14) }\end{array}$ \\
\hline
\end{tabular}

POI, primary omental infarction; $\mathrm{m}$, male; f, female; US, ultrasound; CT, computer tomography. loops prevented the appearance of any hyperechoic mass due to the omental infarct. Furthermore, the clinical, hematological, and secondary US findings of acute appendicitis in this patient were strong indicators of acute appendicitis; CT was thus not performed to investigate the situation further. Moreover, there are cases in the literature in which CT findings supported the diagnosis of acute appendicitis, but where an alternate cause was occasionally subsequently found, such as omental infarct. ${ }^{2}$ The mass of the omental infarct on CT can be attributed to an inflammatory process in the omentum induced by inflammation of the appendix; the CT results can therefore be falsely positive for acute appendicitis. ${ }^{9}$ The management of POI remains controversial, since the comparative risk of leaving a necrotic segment of omentum in the abdomen versus the risk of surgery is not known. ${ }^{4}$ Some authors advocate conservative treatment with antibiotics, analgesia, and hospitalization when the preoperative diagnosis is confirmed by the imaging studies and the patient's condition is stable. In those uncomplicated cases, conservative treatment is adequate, avoiding the risk of postoperative adhesions, ${ }^{4}$ although the resolution of abnormalities is slow and may last from 4 weeks to 4 months. ${ }^{10}$ However, if the patient experiences acute pain or the symptom complex or physical examination is discordant with the imaging findings, then diagnostic laparotomy or laparoscopy should be the next step in man- agement. 5 0ther authors recommend prompt resection of the inflamed tissue because surgical intervention is associated with a faster recovery and better pain control, and prevents complications such as abscess, possibly sepsis, adhesion formation, and bowel obstruction. ${ }^{4}$

\section{Conclusions}

In conclusion, despite its uncommon occurrence, POI should be considered in the differential diagnosis of acute abdomen, particularly in obese children that is a frequent medical problem now days. Although it is difficult to draw any firm conclusion from a single case, the rapid and uneventful postoperative course of our patient supports early operative intervention, at least in those cases where the preoperative diagnosis is uncertain.

\section{References}

1. Nubi A, McBride W, Stringel G. Primary omental infarct: conservative vs operative management in the era of ultrasound, computerized tomography, and laparoscopy. J Pediatr Surg 2009;44:953-6.

2. Helmrath MA, Dorfman SR, Minifee PK, et al. Right lower quadrant pain in children caused by omental infarction. Am J Surg 2001;182: 729-32.

3. Puylaert JB. Right-sided Segmental infarction of the omentum: clinical, US, and CT findings. Radiology 1992;185:169-72.

4. Varjavandi V, Lessin M, Kooros K, et al. Omental infarction risk factors in children. $\mathrm{J}$ Pediatr Surg 2003;38:233-5.

5. Loh MH, Chui HC, Yap TL, et al. Omental infarction-a mimicker of acute appendicitis in children. J Pediatr Surg 2005;40: 1224-6.

6. Rimon A, Daneman A, Gerstle JT, et al. Omental infarction in children. J Pediatr 2009; 155:427-31.

7. Baldisserotto M, Maffazzoni DR, Dora MD. Omental infarction in children. Color Doppler sonography correlated with surgery and pathology findings: Am J Roentgenol 2005;184: $156-62$.

8. Schlesinger AE, Dorfman SR, Braverman RM. Sonographic appearance of omental infarction in children. Pediatr Radiol 1999;29:598601.

9. Lee W, Ong CL, Chong CC, et al. Omental infarction in children: imaging features with pathological correlation. Singapore Med J 2005;46:328-32.

10. Foscolo S, Mandry D, Galloy MA, et al. Segmental omental infarction in childhood: an unusual case of left-sided location with extension into pelvis. Pediatr Radiol 2007;37:575-7. 